\title{
PENYUSUNAN (FITTING) DATA TITIK (POINT CLOUD) DARI PROSES PEMINDAIAN (SCANNING) 3 DIMENSI PADA PRODUK CYLINDER HEAD COVER
}

\author{
Pujiyanto dan Shinta Virdhian \\ Balai Besar Logam dan Mesin, Kementerian Perindustrian \\ Jalan Sangkuriang No. 12 Bandung, Jawa Barat \\ pujiyanto_bblm@yahoo.co.id, shinta_va@yahoo.com
}

\begin{abstract}
ABSTRAK
Mesin pemindai tiga dimensi merupakan suatu alat pemindai titik-titik pada permukaan suatu obyek benda kerja. Keluaran dari alat pemindai ini adalah data titik (point cloud) yang merupakan suatu set data titik titik dalam sistem koordinat. Data-data titik ini digunakan untuk membuat model CAD 3 dimensi. Pemodelan 3 dimensi ini dapat digunakan dalam proses manufaktur, metrologi/inspeksi, visualisasi, animasi dan lain-lain. Makalah ini bertujuan untuk menyusun data-data titik yang didapatkan dari proses pemindaian produk cylinder head cover sehingga data yang diperoleh dapat disusun mirip perwujudan produk contoh yang dipindai. Tahapan yang dilakukan adalah pemindaian 3 dimensi, perbaikan, penyusunan berkas data, analisa simpangan, dan penyatuan berkas. Dengan tahapan-tahapan itu hasil yang didapatkan diharapan memiliki deviasi rata-rata yang optimum. Hasil analisis deviasi dari data titik-titik (point clouds) menunjukkan bahwa pemindaian berkas pada bagian permukaan luar memiliki batas deviasi rata-rata yang lebih kecil (-0.1983 0.1912) bila dibandingkan dengan pemindaian berkas pada permukaan bagian dalam dari cylinder head cover $(-0.6769 \sim$ 0.6319).
\end{abstract}

Kata Kunci: Point Cloud, 3D Scanning, Analisis Deviasi

\begin{abstract}
Three-dimensional scanner is a scanner points on the surface of an object work piece. The output of this scanner is a data point (point cloud) which is a set of data points in a coordinate system point. These data points are used for various purposes such as creating three-dimensional CAD model required in the manufacturing process, metrology / inspection, visualization, animation and others. This paper aims to compile the data points obtained from scanning product cylinder head cover so that the data obtained can be structured similar to the original embodiment. In addition, the results obtained it calls have an average deviation of the optimum. Results of analysis of the deviation of the data points (point clouds) indicates that the scanning beam on the outer surface has a limit of the average deviation smaller (-0.1983 0.1912) when compared with the scanning beam on the inner surface of the cylinder head cover (- $0.6769 \sim-0.6319)$.
\end{abstract}

Keywords: Point Cloud, 3D Scanning, deviation analysis

\section{PENDAHULUAN}

Perkembangan teknologi desain dan permodelan 3 dimensi berkembang sangat pesat. Pada perkembangannya, dengan teknologi ini banyak digunakan dalam rekayasa peniruan (reverse engineering) maupun rekayasa desain murni. Dengan semakin cepatnya tuntutan pasar, teknologi dalam mendesain suatu produk yang baru juga dituntut semakin efektif dan efisien.

Teknologi desain yang diperkenalkan dalam melakukan desain telah banyak dijual dipasar, baik berupa teknologi perangkat keras (hardware) maupun aplikasi perangkat lunaknya (software). BBLM sebagai lembaga penelitian dan pengembangan (litbang) dalam bidang logam dan mesin telah dilengkapi dengan beberapa perangkat desain yang mutakhir. Peralatan itu berupa perangkat aplikasi CAD (computerized Aided Design) dan mesin pemindai 3 dimensi (3 dimensional scanning machine). Mesin pemindai 3 dimensi digunakan untuk proses pengambilan data geometri dari produk yang berupa sekumpulan titik-titik. Dari titik-titik yang dihasilkan dari proses pemindaian ini diolah dalam perangkat aplikasi CAD menjadi permodelan 3 dimensi dari produk, baik berupa pemodelan kulit (surface modeling) maupun pemodelan pejal (solid modeling). Dari permodelan 3 dimensi 
ini diolah lebih lanjut secara keteknikan hingga dihasilkan produk baru.

Teknologi rekayasa peniruan telah berkembang dengan sedemikian pesatnya hingga inovasi terhadap kebaruan suatu produk dapat dilakukan hanya dalam hitungan bulan. Pada prinsipnya, penguasaan teknologi ini didasari pada pemahaman akan keberfungsian dari suatu elemen, fitur, komponen satuan, komponen sub rakitan, dan produk rakitan melalui persyaratan yang harus dipenuhi secara geometri dan persyaratan kekuatan material.

Dalam melakukan penelitian dan pengembangan (litbang) di BBLM, salah satu fokusnya adalah litbang prototip produksi massal dari pembuatan komponen motor bakar. Dalam produksi massal, pendalaman terhadap setiap fitur yang menyusun bangunan komponen harus dilakukan hingga dapat dipahami fungsi dan persyaratan dari setiap fitur itu. Dengan pemahaman dari fungsi dan persyaratan setiap fitur, maka tujuan dalam mendesain untuk mengidentifikasi ukuran nominal dari fitur dapat diperoleh. Dengan ukuran fitur nominal dapat dibuat simulasi toleransi dimensi dan geometri dari fitur tersebut hingga diperoleh toleransi geometri yang optimum. Tujuan dari kegiatan ini adalah melakukan pemindaian 3 dimensi terhadap produk dengan hasil akhir berupa data titik dengan simpangan yang sangat kecil (dibawah $0,5 \mathrm{~mm}$ ).

Kegiatan ini diawali dengan pemilihan produk yang paling sesuai dengan kemampuan sumber daya yang ada di BBLM. Kemudian dari produk yang dipilih, dilakukan desain ulang melalui penguasaan teknologi rekayasa peniruan. Dari desain ulang ini diteruskan dengan proses manufaktur yang didasari pada hasil desain ulang tersebut.

Untuk kelengkapan data geometri, dalam kegiatan ini dilakukan pengambilan data geometri dengan mesin pemindai 3 dimensi. Proses pengambilan data dilakukan berulang pada posisi dan orientasi yang diubah-ubah hingga data yang dibutuhkan dianggap mencukupi. Data yang diambil disetiap prosesnya tidak serta merta dapat tersusun secara otomatis hingga membentuk perwujudan seperti produk contoh yang dipindai, namun perlu penanganan lebih lanjut hingga diperoleh perwujudan yang diinginkan. Dengan demikian diperlukan langkah-langkah agar data yang diperoleh dapat disusun hingga mirip dengan perwujudan aslinya.
Alat pemindai 3 dimensi ini dipilih karena dalam metode inspeksi secara manual terdapat kendala dalam melakukan pengukuran geometri (ukuran, bentuk, posisi, dan orientasi). Dengan alat pemindai 3 dimensi ini, hasil data yang direkam berwujud sangat mirip dengan produk contohnya (termasuk geometrinya), sehingga setelah data titik diolah dengan menggunakan software pemodelan ulang, dapat dilakukan inspeksi data titik untuk memperoleh informasi geometri yang diperlukan.

Pada tahap penyusunan data titik ini, target yang diharapkan adalah susunan dari data titik di setiap tahapan dengan data yang paling optimum dan deviasi yang paling optimum pula. Untuk memenuhi keperluan ini diperlukan pekerjaan yang iteratif hingga data akhir sebelum dibuat permodelan 3 dimensi adalah data yang paling memudahkan pekerjaan pemodel 3 dimensi (3D modeler).

\section{METODOLOGI}

Penyusunan berkas data titik dianggap baik jika penyimpangan data yang diperoleh sangat kecil. Untuk memperoleh itu semua teknik pemindaian, perbaikan data, penyusunan hingga validasinya dilakukan dengan hati-hati.

Dalam tahapan penyusunan berkas data titik ini menggunakan kombinasi alat berupa software dan hardware. Disamping itu penggunaan alat ukur manual berupa jangka sorong juga diperlukan guna membandingkan ukuran hasil ukur jangka sorong dengan inspeksi dengan software pada data titik tersebut. Pembandingan ini diperlukan untuk melihat besaran penyimpangan data ukur pemindai 3 dimensi terhadap jangka sorong. Hasil inspeksi data titik dengan jangka sorong dianggap sebagai acuan

Software yang digunakan adalah perangkat aplikasi pemodelan 3 dimensi khusus untuk mentransformasikan data titik menjadi pemodelan 3 dimensi, yaitu rapidform 2006. Sedangkan hardware yang digunakan berupa seperangkat komputer desain (work station) merk Dell Precission T 3500 dan seperangkat alat pemindai 3 dimensi merk Konica Minolta Vivid 9i dengan menggunakan lensa jenis wide.

Untuk mengantisipasi kesulitan dalam pemindaian 3 dimensi, diperlukan pula bahan tambahan berupa cairan penutup kilap pada produk, yaitu spots check developer. Bahan ini 
dipilih karena kemudahan penggunaannya, mudah diperoleh di pasaran, dan kemudahan untuk dihilangkan dari permukaan produk. Dalam melakukan penyusunan kumpulan data titik yang diambil dalam banyak tahapan mengikuti alur proses seperti gambar 1 berikut:

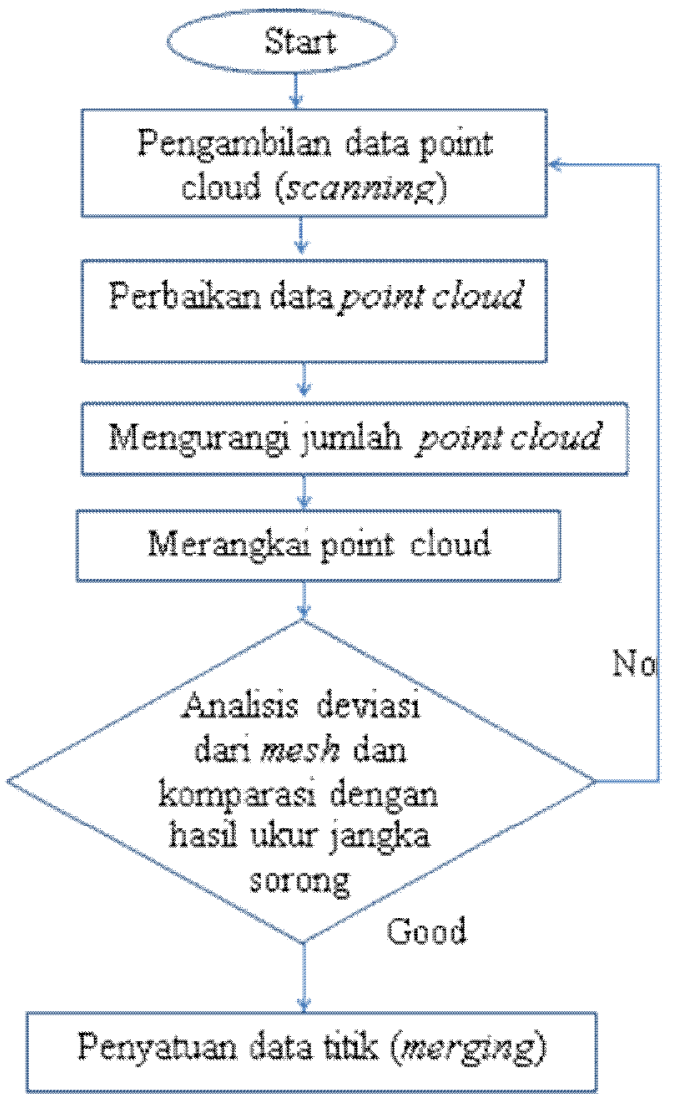

Gambar 1. Alur proses penyusunan data titik (point cloud) produk

Kegiatan ini dimulai dengan pengambilan data titik-titik dari produk contoh yang akan dimodelkan ulang. Proses ini dilakukan dengan melakukan pemindaian 3 dimensi terhadap produk contoh yang diambil. Proses pemindaian 3 dimensi dilakukan berulang-ulang pada sudut pemindaian yang berbeda-beda sehingga ketika setiap berkas pemindaian dari masing-masing sudut pemindaian ini akan dirangkai (fitting) akan membentuk bangunan yang mirip dengan produk contoh. Gambar 2. gambar hasil urutan proses pemindaian 3 dimensi sebelum dilakukan perbaikan (editing) hingga perangkaian (fitting).

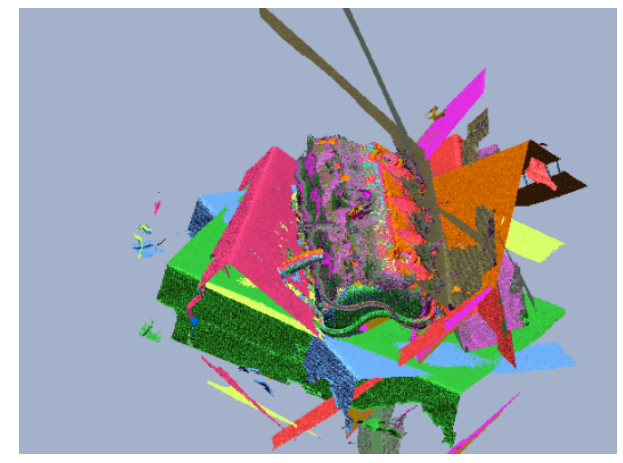

Gambar 2. Hasil pemindaian 3 dimensi

Proses pemindaian dengan hasil seperti gambar 2 dilakukan dengan menempatkan dan memposisikan benda/obyek pindai pada meja bantu pemindai dan peraltan bantu lainnya berupa benda yang dapat digunakan untuk mendudukkan benda itu tetap stabil pada posisi yang diinginkan. Kemudian atur kamera pemindai hingga obyek pindai dapat dipindai seperti yang diinginkan. Kemudian atur software pemindai agar benda pindai diperkirakan dapat dipindai hingga data yang paling maksimal. Setelah semuanya siap, dilakukan pemindaian. Hal ini dilakukan secara berulang dengan cara memutar posisi benda pindai hingga semua sisi dari benda pindai dapat terambil datanya.

Selanjutnya dilakukan perbaikan terhadap hasil pemindaian 3 dimensi. Setiap berkas pemindaian dari sudut pemindaian yang dilakukan, dilakukan perbaikan. Hal ini dilakukan untuk menghilangkan data titik yang sebenarnya bukan dari sampel bagian produk contoh. Lebih dari itu, hasil pemindaian yang dianggap kurang baik seperti menggantung terpisah (dangling), melipat (folded), tidak seragam (non-manifold), bias (noise), dan sebagainya akan dibuang (healing). Kemudian dilakukan perbaikan ujung dari kumpulan titik (edit boundaries) hingga jika titik-tik itu disambungkan menjadi kurva yang halus (smooth). Setelahnya dilakukan perbaikan titik-titk yang berada di sekitar pinggir kumpulan titik, dilanjutkan dengan penghalusan dan perbaikan tampilan, dan diakhiri dengan penutupan lubang-lubang kumpulan titik yang belum terpindai 3 dimensi. Gambar 3 menunjukkan contoh proses perbaikan tiap berkas (file) pemindaian. 


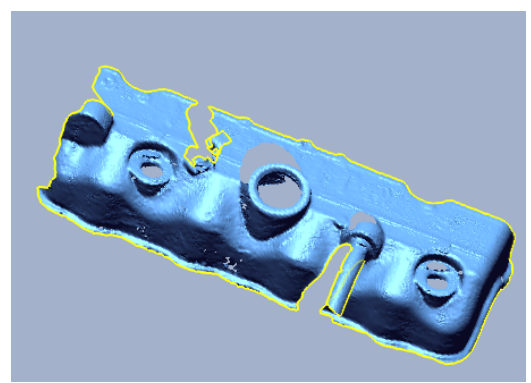

Gambar 3. Contoh hasil proses perbaikan tiap berkas (file) pemindaian.

Setelah hasil perbaikan data titik-titik dianggap optimal, selanjutnya dilakukan pengurangan (decimating) jumlah titik yang ada dalam setiap berkas. Gambar 4 menunjukkan proses pengurangan jumlah titik dalam satu berkas

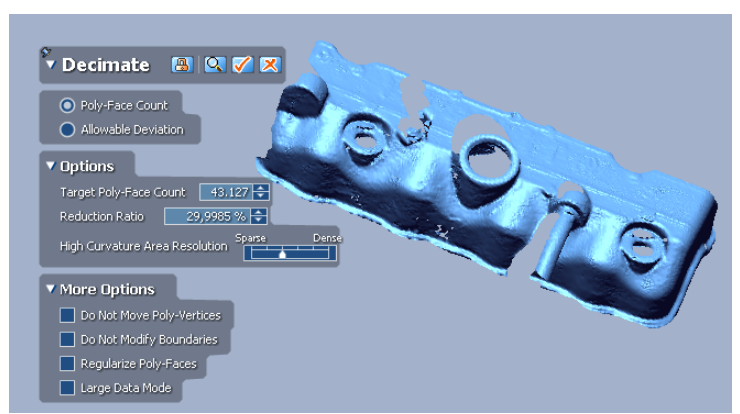

Gambar 4. Proses pengurangan jumlah titik dalam satu berkas

Setelah data setiap berkas pemindaian dikurangi, pekerjaan selanjutnya adalah perangkaian (fitting) setiap berkas menjadi satu rangkaian yang tersusun hingga berwujud mirip dengan produk contohnya. Proses perangkaian dilakukan dengan cara memilih minimal 3 titik pada posisi fitur tertentu dari berkas pilihan awal dirangkai dengan memilih minimal 3 titik pada posisi fitur tertentu yang sama dengan berkas pilihan awal. Gambar 5 menunjukkan hasil perangkaian setiap berkas pemindaian.pada pekerjaan penyatuan setiap berkas ini, sekaligus dilakukan analisis terhadap deviasi antara berkas satu dengan yang lainnya. Hal ini dilakukan untuk melihat besaran penyimpangan hasil pemindaian antara berkas satu dan yang lainnya, termasuk deviasi rata-rata, deviasi maksimum, dan deviasi minimumnya. Gambar 6 menunjukkan analisis deviasi antar 2 berkas data pemindaian 3 dimensi.

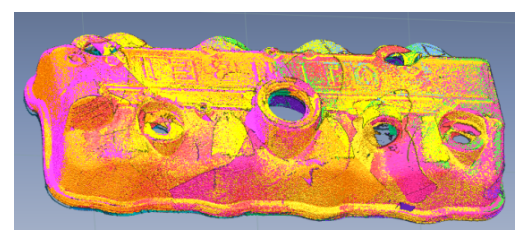

Gambar 5. Hasil perangkaian setiap berkas pemindaian (perbedaan setiap berkas pemindaian dapat dilihat dari perbedaan warna pada tampilan gambar)

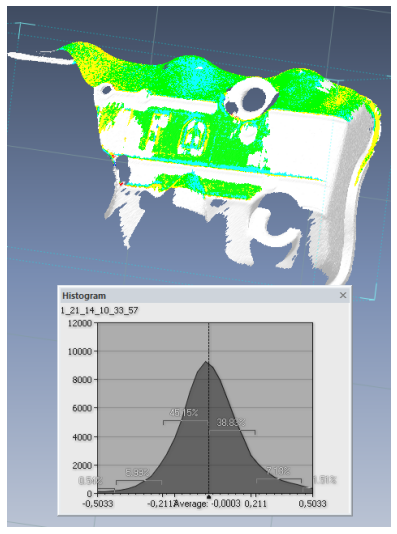

Gambar 6. Analisis deviasi antar 2 berkas data pemindaian 3 dimensi

Setelah berkas-berkas dirangkai menjadi satu rangkaian yang tersusun hingga berwujud mirip dengan produk contohnya, semua berkas itu disatukan (merge) menjadi satu berkas yang merupakan hasil proses peleburan dari seluruh berkas tersusun. Gambar 7 menunjukkan hasil penyatuan seluruh berkas pemindaian 3 dimensi.

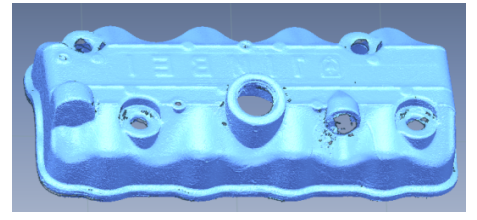

Gambar 7. Hasil penyatuan seluruh berkas pemindaian 3 dimensi

Setelah berkas disatukan menjadi satu, kemudian dilakukan langkah perbaikan ulang terhada berkas yang disatukan hingga proses pengurangan jumlah titik pada berkas tersatukan. Setelah pekerjaan ini dilakukan, selanjutnya data titik-titik ini siap diteruskan pada pekerjaan permodelan 3 dimensi, baik dilakukan secara berbasis fitur (pejal / solid atau kulit / surface) maupun berbasis kulit (NURBS: Non-uniform rational B-spline). 


\section{HASIL DAN PEMBAHASAN}

Dari proses pemindaian yang dilakukan dalam penelitian ini, proses pemindaian dilakukan sebanyak 16 kali proses pemindaian. Dari 16 kali proses ini, 10 kali dilakukan di kulit pada sisi kulit bagian luar dan 6 kali dilakukan pada sisi kulit bagian dalam. Masing-masing proses pemindaian dilakukan dengan mengubah orientasi sudut pemindaian sebesar \pm 450 untuk kulit bagian luar, dan \pm 600 untuk kulit bagian dalam.

Tabel 1. Pengurangan jumlah titik dananalisis deviasi

\begin{tabular}{|c|c|c|c|}
\hline No. & $\begin{array}{l}\text { Pemindaian } \\
\text { ke-n }\end{array}$ & $\begin{array}{l}\text { Jumlah } \\
\text { titik-titik } \\
\text { sebelum } \\
\text { diperkecil }\end{array}$ & $\begin{array}{l}\text { Jumlah } \\
\text { titik-titik } \\
\text { setelah } \\
\text { diperkecil } \\
(30 \%)\end{array}$ \\
\hline 1 & 1 & 287.792 & 86.337 \\
\hline 2 & 2 & 299.712 & 89.913 \\
\hline 3 & 3 & 386.875 & 116.061 \\
\hline 4 & 4 & 274.827 & 82.448 \\
\hline 5 & 5 & 292.058 & 87.617 \\
\hline 6 & 6 & 263.840 & 79.152 \\
\hline 7 & 7 & 258.913 & 77.673 \\
\hline 8 & 8 & 288.502 & 86.550 \\
\hline 9 & 9 & 396.336 & 118.899 \\
\hline 10 & 10 & 155.394 & 46.618 \\
\hline 11 & 11 & 261.758 & 78.527 \\
\hline 12 & 12 & 244.690 & 73.407 \\
\hline 13 & 13 & 249.269 & 74.779 \\
\hline 14 & 14 & 253.670 & 76.101 \\
\hline 15 & 15 & 283.290 & 84.987 \\
\hline 16 & 16 & 273.900 & 82.170 \\
\hline 17 & $\begin{array}{c}\text { Penyatuan } \\
\text { data } 1 \text { hingga } \\
16\end{array}$ & 341.294 & 102.388 \\
\hline
\end{tabular}

Setiap berkas dari proses pemindaian 3 dimensi dikurangi jumlah titiknya hingga $30 \%$ untuk mengurangi jumlah besaran data yang akan diolah. Dari data yang sudah diperkecil ini selanjutnya dirangkai dan di analisis deviasinya dari berkas pertama dengan ke 2 , berkas ke 2 dengan ke 3 hingga berakhir pada analaisa deviasi berkas ke 15 dengan yang ke 16. Tabel 1 menunjukkan jumlah data sebelum diperkecil dan setelah diperkecil, dan tabel 2 hasil analisis deviasi rata-rata, maksimum dan mininum.
Tabel 2 Hasil analisis batas maksimum

\begin{tabular}{|c|c|c|c|c|}
\hline No. & $\begin{array}{c}\text { Analisis } \\
\text { deviasi } \\
\text { Antara } \\
\text { berkas } \\
\text { ke-n } \\
\text { dengan } \\
\text { Gabungan }\end{array}$ & $\begin{array}{c}\text { Batas } \\
\text { deviasi } \\
\text { minimum }\end{array}$ & $\begin{array}{c}\text { Persen } \\
\text { Deviasi } \\
\text { rata-rata }\end{array}$ & $\begin{array}{c}\text { Batas } \\
\text { Deviasi } \\
\text { maksimum }\end{array}$ \\
\hline 1 & 1 & -0.1983 & 87.92 & 0.1912 \\
\hline 2 & 2 & -0.2855 & 91.43 & 0.2753 \\
\hline 3 & 3 & -0.3115 & 92.61 & 0.2837 \\
\hline 4 & 4 & -0.2287 & 85.98 & 0.2388 \\
\hline 5 & 5 & -0.2506 & 87.59 & 0.2468 \\
\hline 6 & 6 & -0.2599 & 89.43 & 0.2751 \\
\hline 7 & 7 & -0.2919 & 91.11 & 0.3026 \\
\hline 8 & 8 & -0.2583 & 89.22 & 0.254 \\
\hline 9 & 9 & -0.3131 & 90.92 & 0.2832 \\
\hline 10 & 10 & -0.5065 & 90.35 & 0.4766 \\
\hline 11 & 11 & -0.6413 & 91.72 & 0.4642 \\
\hline 12 & 12 & -0.5317 & 91.85 & 0.4938 \\
\hline 13 & 13 & -0.5844 & 90.71 & 0.5310 \\
\hline 14 & 14 & -0.6610 & 92.52 & 0.5472 \\
\hline 15 & 15 & -0.6769 & 89.64 & 0.6316 \\
\hline 16 & 16 & -0.5127 & 91.54 & 0.5681 \\
\hline
\end{tabular}

Tabel 2 menunjukkan hasil analisis deviasi antara berkas ke-n dengan berkas gabungan. Data titik berkas ke 1 sampai 9 merupakan hasil pemindaian kulit produk bagian luar sedangkan data titik berkas ke 10 sampai berkas ke 16 merupakan hasil pemindaan kulit produk bagian dalam, Berkas 1 dengan berkas gabungan memiliki nilai deviasi yang paling kecil (range batas minimum dan maksimum yang paling kecil) dengan prosentase titik yang berada dalam range tersebut sebanyak $87.92 \%$. Kemudian berkas ke 2 dianalisis deviasinya dengan deviasi gabungan dan seterusnya. Dari Tabel 2 dapat dilihat bahwa berkas ke 15 memiliki nilai deviasi yang paling besar $(-0.6768$ 0.6316).

Dari Tabel 2 dapat dilihat pula bahwa data ke-10 hingga ke-16 memiliki rentang yang lebih lebar dibandingkan dengan data ke-1 hingga ke-9. Hal ini terjadi karena data ke-1 hingga ke-9 merupakan kulit produk bagian luar memiliki keleluasaan sudut pemindaian yang lebih baik dibanding data ke-10 hingga ke-16. Keterbatasan pemindaian pada data ke10 hingga ke-16 adalah halangan (hidden) dari dinding produk contoh saat laser bergerak memindai. 


\section{KESIMPULAN}

Mesin pemindai 3 dimensi digunakan untuk proses pengambilan data geometri dari produk yang berupa sekumpulan titik-titik. Dari titik-titik yang dihasilkan dari proses pemindaian ini diolah dalam perangkat aplikasi CAD menjadi pemodelan 3 dimensi dari produk, baik berupa pemodelan kulit (surface modeling) maupun pemodelan pejal (solid modeling). Pada tahap penyusunan data titik ini, target yang diharapkan adalah susunan dari data titik di setiap tahapan dengan data yang paling optimum dan deviasi yang paling optimum pula. Untuk memenuhi keperluan ini diperlukan pekerjaan yang iteratif hingga data akhir sebelum dibuat pemodelan 3 dimensi adalah data yang paling memudahkan pekerjaan pemodel 3 dimensi ( $3 D$ modeler). Hasil analisis deviasi dari data titik-titik (point clouds) menunjukkan bahwa pemindaian berkas pada bagian permukaan luar memiliki batas deviasi rata-rata yang lebih kecil $(0.1983$ 0.1912) bila dibandingkan dengan pemindaian berkas pada permukaan bagian dalam dari cylinder head cover (-0.6769 0.6319).

\section{DAFTAR PUSTAKA}

1. Berger, M., et.al. 2014. State of the Art in Surface Reconstruction from Point Clouds, Proc. Of Eurographics 2014.

2. Drake, P. 1999. Dimension and Tolerancing Hand Book. New York:Mc Graw-Hill..

3. Ficher, B.R. 2004. Mechanical Tolerance and Stack Up and Analysis. New York:CRC Pers.

4. Huang, M. and Zhong, Y. 2008. Dimensional and geometrical tolerance balancing in concurrent design. Int. Journal Advance Manufacturing Technology. 35, 723-735.

5. Hu, J. and Xiong, G. 2005. Dimensional and geometrical tolerance design based on constraint. Int. Journal Advance Manufacturing Technology. 26(9-10), 1099-1108

6. Salomons et.al. 1996. A Computer Aided tolerancing tool I: Tolerance Specification. Computer in Industry. 31. 161-174.

7. Rabbani, T., et.al. 2006. Segmentation of point clouds using smoothness constraint. IAPRS Volume XXXVI, Part 5, Dresden 25 27 September 2006.

8. Stoll, C., et.al. 2006. Template deformation for point cloud fitting. Eurographics Symposium on Point-Based Graphics 2006.

9. Voelcker, H.B. 2002. Whiter Size in Geometric Tolerancing?. Proc. Of ASPE Summer Tropical Meeting on Tolerance Modeling and Analysis. ASPE Press, Raleigh, USA.

10. Whitney, D.A. 2004. Mechanical Assemblies, Their Design, Manufacture, and Role in Product Development, Oxford University Press, New York, USA. 